https://helda.helsinki.fi

\title{
The Monotheism of the Deuteronomistic History
}

\section{Pakkala, Juha}

2007

Pakkala , J 2007 , ' The Monotheism of the Deuteronomistic History ' , SJOT : Scandinavian journal of the Old Testament. , vol. 21 , no. 2 , pp. 159-178 . https://doi.org/10.1080/09018320801896500

http://hdl.handle.net/10138/329554

https://doi.org/10.1080/09018320801896500

cc_by_nc

acceptedVersion

Downloaded from Helda, University of Helsinki institutional repository.

This is an electronic reprint of the original article.

This reprint may differ from the original in pagination and typographic detail.

Please cite the original version. 


\section{The Monotheism of the Deuteronomistic History Juha Pakkala}

\section{INTRODUCTION}

Although the Hebrew Bible is usually regarded as a monotheistic document, in many of its parts monotheism represents only a thin layer. It contains various, partly contradictory conceptions of the divine. Some passages deny the existence of other gods, whereas others take their existence for granted. The different authors and editors have imparted their views to the Hebrew Bible so that the final text does not contain a consistent view. There is a gradual development from polytheistic to more monotheistic conceptions. In order to understand this development, it is necessary to distinguish its phases, which is possible only with a literary and redaction critical approach that separates texts of different authors and editors. Using the final text would, at best, provide a very general picture of Israel's history of religion, or, at worst, provide a much distorted picture.

In this paper, I will concentrate on the Deuteronomistic History $(=\mathrm{DH})$ its monotheistic passages. Traces of monotheism can only be found in some of the youngest passages of this composition. Although few in number, they provide crucial information about the origin and nature of Biblical monotheism. The $\mathrm{DH}$ is a significant source for understanding the development of Israel's religion from polytheism to monotheism, because it contains texts from a broad time span, beginning with preexilic times and extending well into the Persian Period. The oldest texts were probably written in the

\footnotetext{
${ }^{1}$ I will leave aside the hotly debated questions concerning the Deuteronomistic History, for example, whether the composition was originally composed or compiled by one or many authors. It is clear that many of the later editors were active in these books and it is the activity of these later editors that is of main interest for the present question. Deuteronomy will also be included in this treatment.
} 
preexilic period, but the composition continued to be edited for centuries. Although I will focus on the youngest texts of the $\mathrm{DH}$, it is not possible to understand its monotheism without understanding its roots and background, and therefore I will first provide a short outline of the development before monotheism.

\section{DEVELOPMENT OF ISRAEL's RELIGION BEFORE MONOTHEISM}

The cultural and religious background of early Israel and Judah is, to a great extent, the Canaanite culture of the Late Bronze Age. As far as it can be reconstructed on the basis of Ugaritic texts, the Canaanite religion was polytheistic. In view of the gradual segregation of the Israelite culture from the Canaanite culture, it is probable that the early monarchic religion of Israel was still polytheistic, similar to that of the older Canaanite religion. ${ }^{2}$ Archaeological evidence and vestiges in the Hebrew Bible imply that several gods were worshipped in early Israel. Canaanite divinities of the Bronze Age, such as El, Baal and Asherah, are found in the Hebrew Bible as well as in the Hebrew inscriptions of the Iron Age. $\square^{3}$

However, it is probable that the religion of large city states with wide cultural contacts were more exposed to outward influence than the remote countryside. The constant influence from other regions meant that cultural and economic hubs like Ugarit developed religions with a relatively extensive pantheon that included many divinities. Such cities are melting pots of peoples, cultures and religions, where gods from different

\footnotetext{
${ }^{2}$ For practical reasons, Israel refers to both Judah and Israel in this paper.

${ }^{3}$ Thus according to many, for example, Mark S. Smith, The Origins of Biblical Monotheism: Israel's Polytheistic Background and the Ugaritic Texts (Oxford: Oxford University Press, 2001).
} 
regions were worshipped side by side. Divinities of other regions were gradually integrated into the pantheon.

On the other hand, areas that were not on the main trade routes and thus geographically more isolated were culturally different. Their peripheral location meant that their cultures were more conservative and less open to change. There was more resistance to external influence. ${ }^{4}$ It created a more homogenous culture and religion than what was found in the prosperous and cosmopolitan cities. In the Levant, Judah, Moab, Ammon and Edom, would be such areas. They were poor and not very densely populated. This seems to have resulted in a religion that was more centered on one god or a few gods than the old Canaanite religion of the Bronze Age. This is suggested by the relatively limited number of divinities known from these regions in the Iron Age.

Although evidence is scanty, it is possible that the religion of Israel and especially of the city of Samaria became more heterogeneous in the heyday of the Northern Kingdom. During Omri's dynasty the state became economically prosperous, which meant wide political and cultural contacts with other areas of the Levant. For example, the Book of Kings implies contacts with the Phoenician realm that most likely entailed religious influence. References to Baal in $1 \mathrm{Kgs}$ 16:30-33 may reflect these circumstances. ${ }^{5}$

\footnotetext{
${ }^{4}$ This does not mean that such cultures would not change. The changes only occurred more slowly than in the prosperous and international cities. The same applies to most contexts around the world. The countryside tends to be more conservative than the main cities.

${ }^{5}$ Since 1 Kgs 16:30-33 is heavily edited, one has to be careful with the passage. For details and further literature on the development of Israel's religion during the monarchy, see Juha Pakkala, Intolerant Monolatry (SESJ, 76; Göttingen - Helsinki: Vandenhoeck \& Ruprecht, 1999). See features of Israel's religion described in Mark S. Smith, Origins of Biblical Monotheism; idem, The Early History of God (Grand Rapids - Cambridge: Eerdmans, 2002); Ziony Zevit, The Religions of Ancient Israel: A Synthesis of Parallactic Approaches (London - New York: Continuum, 2001).
} 
Towards the end of the monarchic period, the religion of Judah became even more centered on one God. Although it is probable that Yahweh (or Yahweh-El) $\square^{6}$ already had a relatively dominant position in the religion of Judah earlier, his position was further strengthened by the diminished size of Judah in the late $7^{\text {th }}$ century BCE. With the state comprising only the surroundings of Jerusalem, the temple of Yahweh received a strong position in the whole society. The temple personnel devoted to Yahweh became powerful. The temples of other gods may even have been left outside the borders of Judah. It is probable that for many Judeans Yahweh was the only god during this time. 7 However, there is no evidence that the worship of other gods was explicitly forbidden during the monarchic period. $\square^{\text {An }}$ appropriate designation for the religion of the late $7^{\text {th }}$ century BCE is tolerant monolatry. Such a position towards the divinity is found in other religions as well. For example in Hinduism, an individual may devote himself to one god only, who is then exclusively worshipped as the supreme god. At the same time, other divinities are not opposed or criticized. $\stackrel{9}{\square}$

The destruction of the temple brought about a dramatic change in Israel's religion. Out of the need to protect Israel's identity as a separate religious entity, it was necessary to create stricter borders between Israel and the other nations or peoples. Israelites were allowed to worship only Yahweh, whereas other gods were meant for the other nations. The

\footnotetext{
${ }^{6}$ It is probable that Yahweh and El, originally two different gods, merged in the early monarchic period. See Smith, The Early History, pp. 32-44.

${ }^{7}$ Lesser deities, spirits and demons as well as different kinds of fertility cults and ancestral worship certainly continued to be part of the Israelite religion. It is also probable that Yahweh's consort Asherah had an important position in the monarchic religion of Judah. Her cult was closely connected with Yahweh. ${ }^{8}$ For example, it is highly improbable that the prophets criticized polytheism in the preexilic period, as suggested by Smith, Origins of Biblical Monotheism, 155. The intolerant monotheism of the prophets is dependent on nomistic texts. Most of the literary development of the prophetic books took place in the post587 BCE period.

${ }^{9}$ On this principle, called ishtadeva, see Simon Weightman, "Hinduism”, in John R. Hinnells (ed.) 1997. Handbook of Living Religions (London: Penguin Books), pp. 282-283.
} 
worship of other gods implied that one was not an Israelite. The exclusive worship of Yahweh became fundamentally connected with Israel's identity in relation to other nations.

However, it is important to note that the existence of other gods was not denied at this stage. They had a function in being the gods of other nations. In fact, it was assumed that non-Israelites continued to worship their gods. This would guarantee the separation between Israel and the other nations. One can call such a position where the worship of other divinities is prohibited without denying their existence intolerant monolatry. The position is well represented in the final text of the Hebrew Bible because many central texts, especially in Deuteronomy and the $\mathrm{DH}_{\square}^{10}$ were mainly or completely written and edited by nomistic editors, $\square^{11}$ the main advocates of intolerant monolatry. $\square^{12}$ It should be added that intolerant monolatry was probably born among the exiles. It was only gradually accepted by the wider Jewish community. $\square^{13}$

Intolerant monolatry was not the final phase of the development. The DH contains some passages which can be characterized as monotheistic: Deut 4:32-40; Deut 7:7-11; 2 Sam 7:22-29; 1 Kgs 8:54-61; 1 Kgs 18:21-40 and 2 Kgs 19:15-19. In addition to other distinct features, the explicit denial of the existence of other gods sets them apart from the monolatric texts and from all older texts of the DH. It is evident that these texts represent a distinct phase in the history of Israel's religion. Although few in number, they are

\footnotetext{
${ }^{10}$ The final text of passages such as Deut 13 and 2 Kgs 23 are mainly nomistic.

${ }^{11}$ With nomistic editors I refer to the late deuteronomistic editors who elevated the law to the center of religion. In the past, they have often been referred to as DtrN (and DtrB). It is probable that the nomists consist of successive editors who were active during a long period beginning from the late $6^{\text {th }}$ century BCE. For details, see Timo Veijola, "Bundestheologische Redaktion im Deuteronomium" in Timo Veijola (ed.) 1996, Das Deuteronomium und seine Querbeziehungen (SESJ, 62; Göttingen - Helsinki: Vandenhoeck \& Ruprecht), pp. 242-276; Pakkala, Intolerant Monolatry, pp. 214-222.

${ }^{12}$ For more details on tolerant and intolerant monolatry, see Pakkala, Intolerant Monolatry, pp. 15-17.

${ }^{13}$ For example, the Jewish community of Elephantine seems to have been unaware of the prohibition against worshipping other gods still in $5^{\text {th }}$ century BCE.
} 
significant historical witnesses because they show how monotheism developed from older conceptions.

\section{MONOTHEISTIC TEXTS AS LATER ADDITIONS}

It seems probable that all monotheistic texts of the $\mathrm{DH}$ are later additions to their contexts. This can be seen in the way they relate to the ongoing story and narrative. They often digress from the context and its themes so that their removal would not disturb its general flow, and in most cases, would make it clearer. Their use of language and vocabulary as well as dependency on late texts in other parts of the Hebrew Bible also betrays them as later additions.

Deut 4:32-40

Deut 4 is generally assumed to be one of the youngest chapters in Deuteronomy. $\square^{14}$ This is seen in the explicit references to the exile and even to the time after the exile (vv. 25-30). A very late stage in the development of the book is also pointed to by the fact that the author refers to an existing Torah (התורה הזאת in v. 8 and זאת התורה in v. 44), implying that it is already an established written collection of laws given by Yahweh through Moses. Such a position towards the Torah is only met in young texts of the Hebrew Bible.

\footnotetext{
${ }^{14}$ Thus, e.g., Antti Filemon Puukko, Das Deuteronomium. Eine literarkritische Untersuchung (BWAT, 5; Leipzig, 1910), pp. 132-138; Gustav Hölscher, "Komposition und Ursprung des Deuteronomiums", ZAW 40 (1923), pp. 167-168; Dietrich Knapp, Deuteronomium 4 (GTA, 35; Göttingen, 1987), pp. 112-113 and Veijola, Bundestheologische Redaktion, pp. 258-259.
} 
The chapter was evidently heavily edited. $\square^{15}$ Deut 4:32-40, important for the present question, is usually regarded as the youngest addition to the chapter. $\square^{16}$ It is a discourse dependent on the preceding text but which develops it in a new direction and contains a new theme. The exile and its consequences are central in the preceding verses, but this theme recedes into the background in vv. 32-40, which center around the idea that Yahweh is the only God. The preceding text also deals with the other gods, but the position towards them is different in vv. 32-40. Deut 4:15-20 still assumes that the heavenly bodies are divine in some way. The main idea in these verses is that it is prohibited for the Israelites to worship them (see especially v. 19). However, for the author of vv. 32-40, the other gods do not exist. Only Yahweh is God (אין עוד מלבדו). Consequently, vv. 32-40 should be regarded as the latest major addition to one of the youngest chapters of the book, which puts the passage at the very end of the book's development.

Deut 7:7-11

Like Deut 4, Deut 7 belongs to the parenetic section of Deuteronomy that provides instructions and exhortations to follow the law and its commandments. Deut 7 primarily contains material from the later phases in the development of the book. Many scholars assume that the chapter was heavily edited. Already the variety of themes implies that it

\footnotetext{
${ }^{15}$ Thus already Carl Steuernagel, Einleitung in das Alte Testament (Tübingen: J. C. B. Mohr - Paul Siebeck, 1912), pp. 173-174.

${ }^{16}$ E.g., Knapp, Deuteronomium 4, pp. 105-111; Martin Rose, Der Ausschliesslichkeitsanspruch Jahwes. Deuteronomische Schultheologie und die Volksfrömmigkeit in der späten Königszeit (BWANT, 106; Stuttgart - Berlin - Köln - Mainz, 1994), p. 491; Timo Veijola 2004, Das 5. Buch Mose, Deuteronomium (ATD, 8/1; Göttingen: Vandenhoeck \& Ruprecht), pp. 114-115.
} 
was written by several successive authors. $\square^{17}$ Our interest lies in vv. 7-11, which seem to form a short theological treatise dealing with the question of why Yahweh chose Israel. Although related to the rest of the chapter, these verses are probably a later addition inspired by v. 6 which refers to the election. $\square^{18}$ A later editor wanted to elaborate on the reasons for the election. The secondary nature of this passage is also seen in the way the author of v. 11. returns to the theme of v. 12, thus repeating instructions to follow the commandments. It is typical of later editors to try to return to the theme or vocabulary of the older text at the end of the expansion. The removal of vv. 7-11 would not disturb the story in the rest of the chapter. Consequently, it is often rightly assumed that vv. 7-11 were added by a later hand. $\square^{19}$ Since even the older text in vv. 1-6 derives from the nomists, $\square^{20}$ it is evident that vv. 7-11 belong to the latest additions to the book. The difference between the nomistic text, which still implies the existence of other gods (e.g., v. 4) and vv. 7-11, which explicitly state that the other gods do not exist, is clear. That the monotheistic vv. 7-11 were added later to an older monolatric text shows the direction of development in Israel's religion.

$2 \operatorname{Sam} 7: 22-29$

\footnotetext{
${ }^{17}$ For details, see Veijola, Bundestheologische Redaktion, pp. 248-254; idem, Das 5. Buch Mose, pp. 193208; Pakkala, Intolerant Monolatry, pp. 94-96.

${ }^{18}$ See Veijola, Das 5. Buch Mose, p. 206.

${ }^{19}$ E.g., Veijola, Bundestheologische Redaktion, p. 252. However, Gottfried Seitz, Redaktionsgeschichtliche Studien zum Deuteronomium (BWANT, 93; Stuttgart, 1971), pp. 74-79, also includes vv. 12-15 in this addition.

${ }^{20}$ For the nomistic origin of vv. 1-6, see Veijola, Bundestheologische Redaktion, pp. 248-254. Nomistic vocabulary and theology is also found in the rest of the chapter. For example, the instructions to follow the commandments and threats of punishment if one fails to follow them in v. 12 as well as the idol criticism in vv. 25-26 show nomistic characteristics.
} 
2 Sam 7:18-29 contains David's prayer after the prophet Nathan had delivered him Yahweh's promise that David's dynasty would be eternal (vv. 1-17). Verses 18-29 are evidently dependent on the promise. In vv. 18-21 David contemplates the wondrous nature of the promise, but the theme is changed in vv. 22-24. The perspective is widened from the house of David to the whole of Israel. These verses describe how Yahweh redeemed Israel from Egypt (v. 23) and how he made Israel his own people. In addition, Yahweh's character (v. 22) is discussed. In other words, vv. 22-24 contain issues that seem to be unrelated to their context. Yahweh's deeds in Egypt fit poorly to Nathan's promise to David. One should also note how the theme and vocabulary of v. 21 is connected to v. 25 . Verse 21 directly refers to Yahweh's promise, brought up again in v. 25. In order to return to the older text, some of the repetition in v. 25 may have been created by the editor who added vv. 22-24. Accordingly, many scholars assume that vv. 22-24 derive from a later editor $\square^{21}$ The addition is usually attributed to the nomistic circles, but, on the basis of vocabulary and thematic connections with other post-nomistic texts, Petri Kasari has recently argued that a later date may be more probable. ${ }_{\square}^{22}$

Verse 28 may also be a later addition to the prayer. Verse 27 refers to a petition that is expected to follow (להתפלל אליך את־התפלה הזאת). However, the petition to bless is not provided before v. 29 (ועתה הואל וברך ...). Verse 28 digresses to praise Yahweh that his words have been fulfilled. The beginnings of vv. 28 and 29 are also noteworthy: Both begin with the word ועתה. Likewise, both vv. 27 and 28 finish with the same word הזאת. It is

\footnotetext{
${ }^{21}$ Thus, among others, Timo Veijola, Die ewige Dynastie. David und die Entstehung seiner Dynastie nach der deuteronomistischen Darstellung (AASF B, 193; Helsinki, 1975), p. 74; Richard Nelson, The Double Redaction of the Deuteronomistic History (JSOT.S, 17; Sheffield, 1981), p. 106; Petri Kasari, Nathan's Promise in 2 Samuel 7 and Related Texts (Diss. at the Åbo Akademi, Finland, 2004), pp. 88-90. The beginning of v. 25 could also derive from the editor.

22 Kasari, Nathans's Promise, p. 90.
} 
typical of later editors to repeat elements of the older text in order to create a smoother transition between the addition and the older text. In order not to cause a disruption of the passage, an editor often started the addition with the same word that the older text would have continued. Consequently, v. 28 should also be regarded as a later addition to the basic text of the prayer. The context of v. 28 is also related to vv. 22-24. Both contain monotheistic formulations, which do not seem to fit to the rest of the prayer. It is therefore probable that vv. $22-24$ and 28 were added by the same editor. It is noteworthy that in 1 Kgs 8 and 2 Kgs 19:15-19 similar monotheistic formulations were also added to a prayer (see below).

Georg Hentschel has suggested that already the basic text may be exilic. The question about the continuity of the dynasty would have become acute only after king Zedekiah had been deposed by the Babylonians. $\square^{23}$ In addition, by referring to a distant time in the future (למרחק) in v. 19, the author probably had a concrete context in mind when the future of the dynasty was an acute issue. It stands to reason that in the background is a situation when the last king was deposed and when one had to consider what would now happen to the dynasty and the royal line. The author of the prayer wanted to rule out the possibility that the dynasty would not continue. If the basic text is already exilic, the assumption that the additions in vv. $22-24$ and 28 belong to considerably later editorial phases of the composition is corroborated.

\section{Kgs 8:60}

\footnotetext{
${ }^{23}$ Georg Hentschel, 1.Könige (NEB, 10; Würtzburg, 1994), pp. 32. Some scholars assume that the basic text is pre-deuteronomistic, for example, Kyle McCarter, II Samuel (Anchor Bible, 9; Garden City: Doubleday \& Company, 1984) pp. 240-241, but this is improbable; see, e.g., Veijola, Die ewige Dynastie, p. 74.
} 
$1 \mathrm{Kgs} 8$ describes the final preparations for the temple after it had been built. The Ark of the Covenant is brought to the temple in vv. 1-13, followed by Solomon's speech, prayer and the consecration of the temple in the rest of the chapter. Our interest lies in the consecration, which is found in vv. 54-66. These verses use language and ideas familiar from the priestly texts. $\square^{24}$ Some scholars have rightly argued that we are dealing with one of the latest editorial layers of the $\mathrm{DH}$. The author of the passage combines nomistic theology with priestly ideas from different parts of the Pentateuch. $\square^{25}$ As in the previous passages, the author is dependent on the nomistic tradition but is already familiar with later theological ideas and vocabulary.

Würthwein has further suggested that vv. 59-60 are a later addition to the already late passage. $\square^{26}$ This is possible, but would not change the probability that most of the passage in vv. 54-66 derives from authors who were already familiar with priestly theology. $\square$ It is also noteworthy that the monotheistic editors seem to have been particularly active in prayers like 2 Sam 7:18-29,; 1 Kgs 8 and 2 Kgs 19:15-19.

\section{Kgs 18:21-40}

$1 \mathrm{Kgs} 18: 21-40$ is very probably a later addition to the chapter. Verse 41 continues from the primary theme of vv. 1-2, which deal with drought. The text in vv. 3-40 deals with other issues such as the persecution of the prophets and the confrontation between Elijah and the

\footnotetext{
${ }^{24}$ See for example, Kasari, Nathans's Promise, pp. 145-146, 247-249.

${ }^{25}$ Hölscher, "Komposition und Ursprung des Deuteronomiums", p. 168; Hentschel, 1.Könige, p. 63; Kasari, Nathan's promise, pp. 145-146, 247-249. Already, Steuernagel, Einleitung, pp. 356-357, pointed out that many parts of $1 \mathrm{Kgs} 8$ refer to the exile and that the chapter contains very late material.

${ }^{26}$ Ernst Würthwein, Die Bücher der Könige 1 Kön. 1-16 (ATD, 11/1; 2. Göttingen: Vandenhoeck \& Ruprecht, 1985), p. 96.

${ }^{27}$ Kasari, Nathan's promise, pp. 137-155, argues that the passage also contains some vestiges from an older source and editorial layers especially in vv. 62, 65-66.
} 
prophets of Baal. The drought plays only a marginal role in these verses. According to vv. 1-2 there is great famine in the land due to the drought. In v. 1, Yahweh commands Elijah to go to see Ahab, after which Yahweh will let it rain (לך הראה אל־אהאב ואתנה מטר על־פני האדמה). According to v. 2, Elijah went to see Ahab (וילך אליהו להראות אל־האב). The passage is logically continued in v. 41, where Elijah promises Ahab that it will rain. However, vv. 3-40 imply that instead of Elijah going to see Ahab, Ahab had to go to see Elijah (v. 16), followed by Elijah's request that Ahab summon the nation to Mt. Carmel, where Elijah confronts Baal's prophets. The scene on Mt. Carmel (vv. 21-40) never refers to Ahab. In v. 41 then, without any reference to a location, Elijah talks to Ahab alone. Note that v. 40 had brought the scene to Wadi Kishon. All Israel is assumed to be present. The reader is puzzled. What happened to the people in v.41? Is the discussion between Ahab and Elijah taking place at Wadi Kishon? Why is Ahab not mentioned in the main scene? It is evident that the text is the result of heavy editing.

It is probable that the original text continued from vv. 1-2 to v. 41, although some vestiges of the this text may also be preserved in vv. 3-20. At any rate, the scene on Mt. Carmel in vv. 21-40 was added later and seems to be an independent story. The fact that Ahab is not mentioned in this passage suggests that it derives from an external source dealing with Elijah stories similar to those in $1 \mathrm{Kgs} 17$ and 19. If these verses had been written for the present context, one would expect the king to be mentioned.

Verses 3-20 contain texts from different periods and authors, $\square^{28}$ but many of them were probably originally unrelated to the scene on Mt. Carmel. However, vv. 16-20 are necessary for vv. 21-40, because otherwise the latter is incomprehensible in its present

\footnotetext{
${ }^{28}$ See for example, Manfred Köckert, "Von einem zum einzigen Gott. Zur Diskussion der Religionsgeschichte Israels", BThZ 15 (1998), p. 169; Jyrki Keinänen, Traditions in Collision (SESJ 80; Helsinki - Göttingen: Vandenhoeck \& Ruprecht, 2001) pp. 42-78.
} 
context. Verses 16-20 function as a bridge between the scene on Mt. Carmel and king Ahab, because Ahab does not appear in the Mt. Carmel scene itself: Ahab summons the people to Mt. Carmel (v. 19-20). Verses 16-20 also provide a background for the scene. Ahab and the people had worshipped Baal, thus causing trouble (עכר) for Israel. It is unclear whether the drought is meant by this. The connection between Baal and Ahab was probably adopted from $1 \mathrm{Kgs}$ 16:31-32, according to which Ahab worshipped Baal and built a temple for him.

It is likely that $1 \mathrm{Kgs} 18: 21-40$ is younger that the nomists. $\square^{29}$ Already vv. 16-20, which vv. 21-40 are dependent on, at least in the present context (see below), are familiar with nomistic phraseology and theology. Some peculiarities in the phraseology of v. 18 may suggest that we are dealing with a post-nomistic author. The idea that Israel may forget Yahweh's commandments is nomistic, although not often met in this form ( עזב את־מצות יהוה), but the reference to many Baals (הבעלים) is peculiar and may be an indication of a later phase. The nomists usually refer to Baal in the singular and clearly have the name of the divinity in mind. The author of $1 \mathrm{Kgs} 18: 18$ also refers to the Baals with the article, which further suggests that he does not have the name of a deity in mind. One gets the impression that the author's Baals are less than deities. He may already have only idols and objects in mind. Attack on idols is known from late to post-nomistic texts. $\square^{30}$ The author is probably also dependent on the nomistic attack on Baal.

Moreover, Jyrki Keinänen has convincingly demonstrated that vv. 19-20 (as well as v. 40) were later added to v. 18 in order to add the following scene on Mt. Carmel to the

\footnotetext{
${ }^{29}$ However, some scholars have found a pre-deuteronomistic layer in the passage; for example, Ernst Würthwein, Die Bücher der Könige 1.Kön. 17-2.Kön. 25 (ATD, 11/2; Göttingen, 1984), pp. 207-220.

${ }^{30}$ The emphasis on the material aspect of other gods began after classical intolerant Monolatry; see Pakkala Intolerant Monolatry, p. 222.
} 
story. He and other scholars assume that these verses were added in the post-nomistic phase. $\square^{31}$ This is suggested by the lack of typical deuteronomistic and nomistic phraseology and vocabulary. That the Mt. Carmel scene in $1 \mathrm{Kgs}$ 18:21-40 was added in a post-nomistic phase is also suggested by the fact that the author of the text did not consider it problematic to sacrifice outside Jerusalem (see Deut 12). In addition, the author was not offended by the prophets of Baal using the same location for their attempted sacrifice. This would have been impossible for the deuteronomistic or nomistic authors (see $2 \mathrm{Kgs} 23$ ). Since the editor who added $1 \mathrm{Kgs} 18: 21-40$ is dependent on nomistic texts, it is clear that we are dealing with a post-nomistic addition. Of course, this does not rule out the possibility that the scene might have had an earlier origin, but as an addition to the $\mathrm{DH}$, it is postnomistic. $\square^{32}$

$2 \operatorname{Kgs} 19: 15-19$

2 Kgs 19:15-19 (//Isa 37:15-19) contains Hezekiah's prayer to Yahweh after he had received Sennacherib's letter in vv. 9-14. Many scholars have suggested that the prayer is dependent on deuteronomistic language and theology, and, accordingly, it is often ascribed to a deuteronomistic author. $\square^{33}$ However, there are reasons to assume that the prayer is younger. Verse 18 is clearly dependent on Deut 4:28, one of the youngest nomistic

\footnotetext{
${ }^{31}$ See Keinänen, Traditions in Collision, pp. 68-78.

${ }^{32}$ It is probable that $1 \mathrm{Kgs} 18: 21-40$ was also edited, but the lack of typical nomistic themes and phraseology suggests that the development is post-nomistic. For example, Martin Beck, Elia und die Monolatrie. Ein Beitrag zur religionsgeschichtlichen Rückfrage nach dem vorschriftprophetischen Jahwe-Glauben (BZAW, 281; Berlin - New York: DeGruyter, 1999), pp. 70-79, 156-158, argues that the passage continued to develop till the $4^{\text {th }}$ century BCE.

${ }^{33}$ E.g., Würthwein, Bücher der Könige 1.Kön. 17-2.Kön. 25, pp.425-426, 428. However, he assumes that the passage is dependent on Deutero-Isaiah.
} 
additions to Deuteronomy (see also above, Deut 4:32-40), $\square^{34}$ but otherwise obvious deuteronomistic or nomistic language is lacking. $\square^{35}$ According to v. 15, Yahweh had created the heavens and the earth, an idea which is not met in the deuteronomistic or nomistic texts (but cf. Deut 4:32 above). This theme becomes more common in the younger texts such as Deutero-Isaiah.

It is sometimes suggested that the author was familiar with parts of Deutero-Isaiah (Isa $43: 25 ; 48: 11), \square^{36}$ but this connection is not clear. Since it is usually assumed that Deutero-Isaiah was the first to proclaim monotheism, one tends, without closer inspection, to assume that monotheistic features in the $\mathrm{DH}$ are dependent on those texts. On the other hand, some features, such as idol criticism and lack of nationalism (see below), suggest that 2 Kgs 19:15-19 may derive from a different author than the other monotheistic passages of the DH. Therefore, one cannot rule out the possibility that $2 \mathrm{Kgs}$ 19:15-19 was influenced by Deutero-Isaiah. In any case, it seems probable that these verses derive from a postnomistic author belonging to one of the latest editors of the composition. $\square^{37}$

All six monotheistic passages of the DH are probable additions to their contexts and show evidence of later influence. None of them shows typically deuteronomistic or nomistic traits, although they all are dependent on these texts. Especially the passages in

\footnotetext{
${ }^{34} 2$ Kgs 19:18 uses the same phrase when referring to idols as Deut 4:28:מעשה ידי אדם עץ ואבן.

${ }^{35}$ Hentschel, 1.Könige, p. 93, has further suggested that the passage is dependent on Deut 7:5, 25, but this connection is not very clear.

${ }^{36}$ E.g., Würthwein, Bücher der Könige 1.Kön. 17-2.Kön. 25, p. 428; Gwilym Jones, 1 and 2 Kings, 1 Kings 1 16:34 (NCBC, 5; Grand Rapids - London, 1984), p. 577; Hentschel, 2.Könige (NEB, 11; Würtzburg, 1985), p. 93.

${ }^{37}$ Many scholars assume that we are dealing with a very late nomistic text; thus e.g., Hentschel, 2.Könige, 93; Veijola, "Das Bekenntnis Israels", ThZ 48 (1992), p. 532. To some extent, it is only a matter of definition whether we refer to late nomistic or post-nomistic texts, but, because of the lack of typical nomistic features and because of the author's familiarity with creation, not met in other nomistic texts, it may be more appropriate to characterize the text as post-nomistic.
} 
Deuteronomy use extensively nomistic language. Also, those passages that do not use clearly nomistic language are incomprehensible without their nomistic contexts. In other words, the passages are additions to already late texts.

Vocabulary and themes in these passages also suggest that we are dealing with late texts. Some of our passages are familiar with priestly themes and vocabulary. Since the texts are dependent on nomistic texts, but contain features that separate them from this group of literature, it is fair to assume that these six texts, representing a new socioreligious phase in Israel's history, were written after the nomists, whose activity is usually dated to the late $6^{\text {th }}$ or early $5^{\text {th }}$ century BCE. $\square^{38}$ Since it is hardly possible to assume that major additions were made to the $\mathrm{DH}$, especially to Deuteronomy, much after the $5^{\text {th }}$ century BCE, it is probable that these texts represent theological conceptions of this century. $\square^{39}$ It is to these conceptions that we will turn next.

\section{TheOlOGiCAl CONCEPTIONS OF THE MONOTHEISTIC PASSAGES}

\section{Yahweh is the Only God}

The most evident common feature of our monotheistic texts is the conviction that Yahweh is the only God. This is expressed with a phrase that is found in all six passages, although in two different forms יהוה הוא האלהים and The latter appears in a direct speech to the divinity and may be an adjustment made due to the context. The repetition of the phrase in the climaxes of our passages implies that it functioned as a confessional

\footnotetext{
${ }^{38}$ For dating of the nomists, see Pakkala, Intolerant Monolatry, pp. 218-222, 233-238.

${ }^{39}$ Minor additions continued to be made much later, but it is hardly possible that entire passages were added much beyond the 5th century BCE after the Torah became an authoritative text.

${ }^{40}$ See Deut 4:35, 39; 7:9; 2 Sam 7:28; 1 Kgs 8:60; 18:37, 39; 2 Kgs 19:15.
} 
formula or a slogan of the circles behind these texts. For example, when Elijah confronted Baal's prophets, he called Yahweh with this formula, and, after Yahweh had demonstrated his power, the Israelites started to repeat the same formula (see $1 \mathrm{Kgs} \mathrm{18:37-39).} \mathrm{Although}$ the confessional formula implies the non-existence of other gods, this is also explicitly declared in Deut 4:35, 39; 1 Kgs 8:60 and 2 Kgs 19:15, 19: e.g., יהוה הוא האלהים אין עוד.

Since the authors often repeated that Yahweh is the only God, it is fair to assume that the idea was not self-evident. One needs to emphasize and repeat an idea in such a way only if it is new or not generally accepted by the audience. In fact, the demonstration that Yahweh is the only God is a central theme in all these passages. For example, Elijah confronted the prophets of Baal in order to show that only Yahweh is a living God and that Baal had no power. The difference in position is clear when we compare these passages with younger texts where monotheism is taken for granted (for example in Chronicles). There was no reason to emphasize the point in such a late stage of Israel's religion, because the Jewish community now already generally accepted that only Yahweh is God. The difference becomes evident when we compare $1 \mathrm{Kgs} 8$ with its younger parallel in Chronicles (2 Chr 6). The author of $1 \mathrm{Kgs}$ 8:60 stressed that only Yahweh is God ( כי יהוה הוא האלהים), but the Chronist, who evidently used $1 \mathrm{Kgs} 8$ as a source, skipped the monotheistic formula altogether. It was unnecessary to emphasize that Yahweh was the only God, because for him it was self-evident. Consequently, the monotheistic passages of the DH were probably written at a stage when monotheism was a newly introduced idea. ${ }_{\square}^{41}$

\footnotetext{
${ }^{41} \mathrm{Cf}$. the Quran, which similarly emphasizes that Allah is one. It was born in a context where the Arab tribes worshipped a variety of gods. In order to introduce the new idea, one had to emphasize the point. It is also possible that there is an internal development in the Quran, as in the Hebrew Bible, from polytheistic conceptions to monotheism. For example sura 53 originally referred to several gods, but parts of the passage were later omitted.
} 


\section{Dependence on Nomistic Texts and Theology}

As we have seen, the monotheistic passages are dependent on nomistic texts. The nomistic influence comprises the terminology and phraseology as well as theological concepts $\square_{\square}^{42}$ Like the nomistic texts, some of our monotheistic texts regard the Law of Moses to be the center of Israel's religion. They were written in a context where the first temple had been destroyed. With the disappearance of the temple cult, the law had become the new backbone of Israel's religion. Although it is probable that the second temple was already built during the time of writing, some of the monotheistic texts still emphasize the law. For example, the future of Israel is made dependent on whether it follows the law or not (e.g., Deut 4:40; 7:9-11; 1 Kgs 8:58, 61). The temple and the temple cult do not play a significant role in any of the texts in question. $\square^{43}$ The authors of these passages build on a religious tradition that had become independent of the temple cult. $\square_{\square}^{44}$

The similarity between the nomists and our monotheistic texts suggests that the nomistic influence is not restricted to a dependence on these texts only, but that the author(s) of at least some of our monotheistic texts represent a later phase of the same tradition. The core theology, especially how the religion is built on obedience to the law, remains similar. To some extent, the differences can also be explained as a result of changed circumstances and a further development within the same theological framework and tradition.

\section{Nationalistic Monotheism}

\footnotetext{
${ }^{42}$ E.g., Deut 4:34, 37-38, 40; 7:9, 11; 1 Kgs 8:61.

${ }^{43}$ Although 1 Kgs 8:54-61 is an addition to the dedication of the temple by Solomon, the focus in this addition is on the law and obedience to it.

${ }^{44}$ This does not mean that they would necessarily be critical of the temple. The fact that one of the passages (1 Kgs 8:54-61) is added after a text that describes the dedication of the temple could imply a positive view of the temple.
} 
Proximity with the nomists is also seen in the way the monotheistic texts have inherited the 'nationalism' $\square^{45}$ of the nomists. The Israel-centered attitude is evident in various features of these passages. Yahweh elected Israel from all the nations to be his own people (Deut 4:37; 7:7-9; 2 Sam 7:24). The election, which plays a central role in these passages, is based on Yahweh's love for Israel and for its ancestors (Deut $4: 37 ; 7: 8$ ) and not on Israel's own deeds or greatness. According to Deut 7:7 Israel was the smallest of the nations. The theme of election is closely tied with Israel's deliverance from Egypt. With his great power, Yahweh took Israel from Egypt and brought the Israelites to their own land. In other words, the argumentation is thoroughly nationalistic and, in part, even hostile to other nations. It is evident that the message was intended only for Israel. The humiliation of Egypt (e.g., in Deut $4: 34,37 ; 7: 8$ ) would not convince any Egyptian. Yahweh's promise to destroy other nations (Deut 4:38) is also not a message that was meant for the other nations. In fact, the text implies that it would not be possible for other nations to join Israel in the worship of Yahweh, even if their own gods did not exist. It is peculiar that according to $1 \mathrm{Kgs} \mathrm{8:60} \mathrm{all}$ nations should still know that Yahweh is the only God, although the passage is clearly meant for Israel only (e.g., v. 54-56).

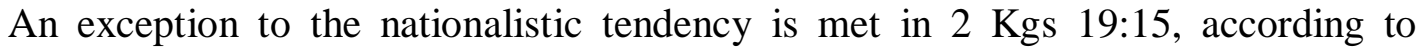
which Yahweh is the only God of all nations (לכל ממלכות הארץ). In this sense, 2 Kgs 19:15-19 is reminiscent of Deutero-Isaiah's monotheism, and therefore, one should not rule out the possibility that $2 \mathrm{Kgs} 19: 15$ derives from an author who was familiar with the monotheism of Deutero-Isaiah (see below).

\footnotetext{
${ }^{45}$ With nationalism I am not referring to nationalism in the modern sense of the word but to the religiously motivated Israel-centered attitude.
} 


\section{History as Proof}

The monotheistic passages frequently appeal to Israel's history as proof that Yahweh is the only God (e.g., Deut 4:32-34; 7:8-9 and 2 Sam 7:22, 28). The authors did not primarily use argumentative logic as a foundation for this conviction. $\square^{46}$ The focus is on Israel's experiences in the desert and Egypt. By his deeds and miracles, Yahweh has shown his power in history. Especially the salvation history in Egypt and in the desert is used as the starting point on the basis of which Israel should be able to understand that Yahweh is truly the only God. The authors imply that only Yahweh is able to intervene in history and help his people in such a way. Although the elements of such argumentation are already present in the older nomistic theology, they now become more prominent and function as proof for monotheism.

The victory over Egypt is closely connected with the monotheistic argumentation because for the author this proves that Yahweh is the only God. Yahweh was in a position to carry out whatever he wanted, even in Egypt. The author(s) of Deut 4:34, 37; 7:8 implied that the gods of Egypt could not challenge Yahweh because they were not real gods. In contrast with the older theology where each god's power was restricted to his land only (see e.g., Deut 32:8-9), in these texts Yahweh's power was extended to other lands as well. This implies a clear extension of Yahweh's realm of power and a removal of the other gods' power.

\section{Creation}

Creation is not an issue in the older passages of the $\mathrm{DH}$, but this is changed in the monotheistic passages. According to Deut 4:32 Yahweh created mankind, whereas

\footnotetext{
${ }^{46}$ In many ways, the argumentation is more rhetorical. Cf. Smith, Origins of Biblical Monotheism, 151-155.
} 
according to $2 \mathrm{Kgs}$ 19:15 Yahweh had also created the heavens and the earth. This aspect fits well with the expansion of Yahweh's realm to the whole world. Since his power extended to other lands, it would be logical to assume that he was also the creator of all lands and people. It is probable that the authors of Deut 4:32 and $2 \operatorname{Kgs} 19: 15$ were familiar with a creation story where Israel's God had created the world, although the references are too vague to determine whether they were familiar with either one or both of the creation stories known to us in Genesis 1-3.

\section{Yahweh Lives in Heaven}

Deut 4:36 refers to God speaking from heaven. This is a new development, dependent on the destruction of the first temple, which also destroyed Yahweh's physical representation. ${ }^{47}$ Earlier texts in the DH had already abandoned the idea that Yahweh actually lived in the temple, but the monotheistic passages show the end of the development. The oldest phases of Deuteronomy contain the earliest attempt to solve the problem with a temple without a physical representation. According to these, only Yahweh's name lived in the temple. $\square^{48}$ However, there is no specific reference to his actual location. Gradually, however, it became necessary to find a solution, and for the monotheistic authors of the $\mathrm{DH}$, Yahweh lived in heaven, whence he also spoke to the

\footnotetext{
${ }^{47}$ It is very likely that Yahweh had a physical representation in the temple. Gods in the Ancient Near East lived in temples. The primary function of a temple was to be a god's house. If Yahweh did not need a house, there would not have been the need to build a temple for him in the first place. However, after the destruction of the first temple, Yahweh did not have a physical representation. It is a probable that his statue was destroyed with the destruction of the first temple. This led to rethinking his presence and an entirely new direction that became one of the features to separate Israel's religion from the other religions of the Ancient Near East.

${ }^{48}$ For example, the deuteronomic version of Deuteronomy already implies that only Yahweh's name lives in the temple (e.g., Deut 12:11, 21, etc.). This may be the earliest reaction to the destruction of Yahweh's statue. About ancient conceptions of a god's presence in the temple, see Edward M. Curtis, "Idol, Idolatry", $A B D, 3$ (1992), pp. 376-381.
} 
Israelites. At this stage, Yahweh was no longer bound to his temple, which had, in practice, become only the 'storeroom' of the Ark of the Covenant, a symbol of a religion based on the law.

The Monotheistic Passages of the DeuteronOMistic History AND DEUTERO-IsAiAH’S MONOTHEISM

The special characteristics of the monotheistic texts of the $\mathrm{DH}$ become clearer when we compare them with the monotheistic texts of Deutero-Isaiah. The differences in the two monotheisms imply that these traditions were not closely connected.

The clearest difference is their attitude towards other nations. Although DeuteroIsaiah is clearly Israel-centered and calls Israel the elected people, he regards it possible that also non-Israelites join Israel in their worship of Yahweh (for example in Isa 45:1823). Such an idea would have been inconceivable in the monotheistic passages of the DH, which, continuing the nomistic tradition, regarded it central to separate Israel from the other nations. Since the worship of Yahweh was closely connected with national identity, the worship of Yahweh by other nations would have been highly problematic. The only exception is $2 \mathrm{Kgs} 19: 15-19$, according to which Yahweh is the God of all nations. This may suggest a closer connection with Deutero-Isaiah.

Another difference between the monotheism of the DH and that of Deutero-Isaiah lies in its attitude towards idols. In Deutero-Isaiah, the two themes are found in the same texts. For example, the author of Isa 44:9-20 argues that since the idols were made by man, the gods they represent cannot be real gods. In the $\mathrm{DH}$, however, monotheism is not connected with idol criticism. The attack on idols is met in different texts that are usually 
older than the monotheistic ones. Again, the only exception in the DH is 2 Kgs 19:15-19, which, like Deutero-Isaiah, attacks the idols.

Since passages that attack the idols in the $\mathrm{DH}$ are generally older than the monotheistic ones, it is possible that idol criticism was a preliminary stage that led to monotheism. Deut 4 is a good example. The older text in v. 28 criticizes the idols as works of man made out of wood and stone, although it does not yet declare that Yahweh is the only God. The idea that other gods are not divine is already implicitly present, but it required a later stage before it was made explicit. As we have seen, a later editor, expanding the chapter in vv. 32-40, made the final step and declared that there is no other God than Yahweh. In other words, the differentiation of these themes in the DH may reveal a preliminary stage, an attack on idols, which may have contributed to the rise of Biblical monotheism.

Although there are clear differences that imply a different context, it is unlikely that the two traditions were completely isolated from each other. Some reciprocal influence is probable, especially in view of the fact that both monotheisms emerged during the same general period. $\prod^{50}$ In any case, for $2 \mathrm{Kgs} 19: 15-19$ one may have to assume a closer connection with Deutero-Isaiah. One should not exclude the possibility that the passage was directly influenced by Deutero-Isaiah.

\section{OBSERVATIONS}

\footnotetext{
${ }^{49}$ It is possible that this connection was made on the basis of Deut 4, where the older text in v. 28 attacks the idols and the addition in vv. 32-40 is monotheistic. If $2 \mathrm{Kgs} \mathrm{19:15-19} \mathrm{was} \mathrm{influenced} \mathrm{by} \mathrm{Deut} \mathrm{4,} \mathrm{the} \mathrm{author}$ could have adopted the connection from the final text of this chapter. Note that $2 \mathrm{Kgs} 19: 18$ is probably dependent on Deut 4:28, as noted above. On the other hand, one cannot rule out the possibility that the connection was adopted from a theological framework close to Deutero-Isaiah where the two themes are explicitly connected in the same texts.

${ }^{50}$ The oldest text of Deutero-Isaiah can be dated to the $5^{\text {th }}$ or $4^{\text {th }}$ century BCE. See for example, Christoph Levin, Das Alte Testament. (Beck'sche Reihe, Wissen 2160; München: C. H. Beck, 3. Auflage, 2006), 86-87.
} 
The Hebrew Bible is often characterized as a monotheistic book, but a closer inspection reveals that monotheistic passages represent only a thin and late layer. There are only six passages in the Deuteronomistic history that contain monotheistic vocabulary. $\square^{\text {They are }}$ late additions that belong to the latest editorial phases of the composition. Because they also postdate the nomistic texts, which are often assumed to represent a very late editorial layer, it is probable that they were added to the composition in the $5^{\text {th }}$ century BCE. This means that the final shift to monotheistic conceptions, as far as the Deuteronomistic History is concerned, occurred in the Persian period. It should also have become evident that the development of Israel's religion from polytheistic conceptions in the early monarchic period to monotheistic ones in the Persian period can only be seen if texts of different periods are differentiated. The relative age of texts can only be determined by a literary and redaction critical approach, without which a considerable amount of information would be lost.

The monotheism of the Deuteronomistic History is 'nationalistic'. Although other gods are assumed to be non-existent, the other nations are not invited to join the Israelites in their worship of Yahweh. One would expect that monotheism undermines nationalism, but this does not seem to be the case. The Israel-centered approach of the nomists continues in monotheism. This also reveals the preliminary stage of the monotheism. It is improbable that there is a planned religious system behind the monotheistic passages of the

\footnotetext{
${ }^{51}$ Smith, Origins of Biblical Monotheism, 154-155, also notes that the rarity of monotheistic rhetoric in the Hebrew Bible is striking.
} 
Deuteronomistic History. The authors are convinced that there is no other deity but Yahweh, but all the consequences of this view have not yet been drawn. 52

The influence of nomism is not restricted to 'nationalism', for the monotheism of the Deuteronomistic History is profoundly influenced by nomistic theology. In fact, some of our monotheistic passages seem to continue in the law-based nomistic tradition to the extent that they can be characterized as representatives of a later phase of the same tradition. Deut 4:32-40 and 7:7-11 in particular use core nomistic phraseology in their exhortations to follow the law. Argumentation on the basis of history, especially Israel's experiences in Egypt and the desert, is also done in a way similar to the nomistic theology.

Other features in the passages reveal that we are dealing with a new phase, postdating classical nomism. Yahweh has already created humankind as well as the whole world. This idea is not found in the older texts. It is probable that the monotheistic authors are dependent on a later form of the Pentateuch, which already includes a creation story. The idea that Yahweh lived in heaven, whence he spoke to the Israelites, is also late. It is the end of the development caused by the destruction of Yahweh's physical representation in the temple where he lived: Yahweh moved to heaven.

Differences between the monotheism of the Deuteronomistic History and DeuteroIsaiah are evident. Deutero-Isaiah is more open to the possibility that other nations worship Yahweh. He does not represent the same tradition as the nomists and he is not indebted to their texts. Deutero-Isaiah also makes a connection between idol criticism and monotheism, whereas in the Deuteronomistic History these themes are found in different texts. Idol criticism seems to be older than monotheism. The differences between the monotheism of

\footnotetext{
52 According to Smith, Origins of Biblical Monotheism, 151-155, assumes that the monotheism of the Hebrew Bible is on a rhetorical level, designed to persuade, reinforce and assert.
} 
the Deuteronomistic History and Deutero-Isaiah suggest that, with the exception of $2 \mathrm{Kgs}$ 19:15-19, neither monotheism is dependent on the other. Although some mutual interaction and influence should not be excluded, they seem to be two distinct developments that took place in different contexts.

While external influence is also possible, $\square^{53}$ it seems that many roots of the monotheism of the Deuteronomistic History can be found in the older conceptions of Israel's religion and especially in the nomistic theology, which is a product of the events in 587 BCE. It is probable that without the destruction of the temple Israel's religion would not have developed monotheistic conceptions. In view of the literary development in the Deuteronomistic History, any pre-587 BCE dating of monotheistic conceptions or phraseology is improbable. $\square^{54}$

\section{BIBLIOGRAPHY:}

Beck, Martin. 1999, Elia und die Monolatrie. Ein Beitrag zur religionsgeschichtlichen Rückfrage nach dem vorschriftprophetischen Jahwe-Glauben (BZAW, 281; Berlin - New York: DeGruyter).

Curtis, Edward M. 1992, "Idol, Idolatry”, $A B D$, 3. 376-381.

Hentschel, Georg. 1984, 1.Könige (NEB, 10; Würtzburg). . 1985, 2.Könige (NEB, 11; Würtzburg).

Hölscher, Gustav. 1923, “Komposition und Ursprung des Deuteronomiums”, ZAW 40. Jones, Gwilym. 1984, 1 and 2 Kings, 1 Kings 1-16:34 (NCBC, 5; Grand Rapids - London)

\footnotetext{
${ }^{53}$ Since monotheistic conceptions do not emerge before the Persian period, Zoroastrian influence should not be excluded.

${ }^{54}$ For example, Smith, Origins of Biblical Monotheism, 153-154, assumes that monotheistic phraseology emerged already before the Exile, although he also admits that most of the references to monotheism derive from the exilic period or later.
} 
Kasari, Petri. 2004, Nathan's Promise in 2 Samuel 7 and Related Texts (Dissertation at the Åbo Akademi, Finland).

Keinänen, Jyrki. 2001, Traditions in Collision (SESJ, 80; Helsinki - Göttingen:

Vandenhoeck \& Ruprecht).

Knapp, Dietrich. 1987, Deuteronomium 4 (GTA, 35; Göttingen).

Köckert, Manfred. 1998, "Von einem zum einzigen Gott. Zur Diskussion der Religionsgeschichte Israels", BThZ 15, pp. 137-175.

McCarter, Kyle 1984, II Samuel (Anchor Bible, 9; Garden City: Doubleday \& Company).

Nelson, Richard. 1981, The Double Redaction of the Deuteronomistic History (JSOT.S, 17; Sheffield: Sheffield University Press).

Pakkala, Juha. 1999, Intolerant Monolatry (SESJ, 76; Göttingen - Helsinki: Vandenhoeck \& Ruprecht).

Puukko, Antti Filemon. 1910, Das Deuteronomium. Eine literarkritische Untersuchung (BWAT, 5; Leipzig).

Rose, Martin. 1994, Der Ausschliesslichkeitsanspruch Jahwes. Deuteronomische Schultheologie und die Volksfrömmigkeit in der späten Königszeit (BWANT, 106; Stuttgart - Berlin - Köln - Mainz).

Seitz, Gottfried. 1971, Redaktionsgeschichtliche Studien zum Deuteronomium (BWANT, 93; Stuttgart: Kohlhammer).

Smith, Mark S. 2001, The Origins of Biblical Monotheism: Israel's Polytheistic Background and the Ugaritic Texts (Oxford: Oxford University Press).

Eerdmans). . 2002, The Early History of God (Grand Rapids - Cambridge:

Steuernagel, Carl. 1912, Einleitung in das Alte Testament (Tübingen: J. C. B. Mohr - Paul Siebeck).

Veijola, Timo 1975, Die ewige Dynastie. David und die Entstehung seiner Dynastie nach der deuteronomistischen Darstellung (AASF B, 193; Helsinki: Suomalainen tiedeakatemia). 1992, “Das Bekenntnis Israels”, ThZ 48, pp. 369-381.

(ed.). 1996, Das Deuteronomium und seine Querbeziehungen (SESJ, 62;

Göttingen - Helsinki: Vandenhoeck \& Ruprecht). . 2004, Das 5. Buch Mose, Deuteronomium (ATD, 8/1; Göttingen:

Vandenhoeck \& Ruprecht). 
Weightman, Simon. 1997, "Hinduism", in John R. Hinnells (ed.), Handbook of Living Religions (London: Penguin Books), pp. 261-309.

Würthwein, Ernst. 1984, Die Bücher der Könige 1.Kön. 17-2.Kön. 25 (ATD, 11/2;

Göttingen: Vandenhoeck \& Ruprecht).

1985, Die Bücher der Könige 1 Kön. 1-16 (ATD, 11/1; 2. edition;

Göttingen: Vandenhoeck \& Ruprecht).

Zevit, Ziony. 2001, The Religions of Ancient Israel: A Synthesis of Parallactic Approaches (London - New York: Continuum). 